\begin{tabular}{|l|l|l|}
\hline \multicolumn{2}{|c|}{ PublisherInfo } \\
\hline \hline PublisherName & $:$ & BioMed Central \\
\hline \hline PublisherLocation & $:$ & London \\
\hline \hline PublisherImprintName & $:$ & BioMed Central \\
\hline \hline
\end{tabular}

\title{
Maternal mutation in trans
}

\begin{tabular}{|l|l|l||}
\hline \multicolumn{2}{|c|}{ ArticleInfo } \\
\hline \hline ArticleID & $:$ & 3979 \\
\hline \hline ArticleDOI & $:$ & $10.1186 /$ gb-spotlight-20010215-01 \\
\hline \hline ArticleCitationID & $:$ & spotlight-20010215-01 \\
\hline \hline ArticleSequenceNumber & $:$ & 50 \\
\hline \hline ArticleCategory & $:$ & Research news \\
\hline \hline ArticleFirstPage & $:$ & 1 \\
\hline \hline ArticleLastPage & $:$ & 2 \\
\hline \hline & & RegistrationDate : 2001-02-15 \\
ArticleHistory & $:$ & OnlineDate \\
\hline \hline ArticleCopyright & $:$ & BioMed Central Ltd2001 \\
\hline \hline ArticleGrants & $:$ & \\
\hline \hline ArticleContext & $:$ & 130592211 \\
\hline \hline
\end{tabular}




\section{Jonathan B Weitzman}

Email: jonathanweitzman@hotmail.com

Irradiation of pre-meiotic stage germ cells was shown to cause germline mutation of mouse minisatellite sequences. In the February 13 Proceedings of the National Academy of Science, Niwa and Kominami report on the effect of irradiation on paternal and maternal minisatellite alleles (Proc Natl Acad Sci USA 2001, 98:1705-1710). They examined length change mutation of the mouse hypervariable minisatellite locus Ms6hm. Male mice were irradiated at the testicular level with 6 gray (Gy) of $\gamma$-ray irradiation and crossed with non-irradiated females. The mutant frequency of the paternal allele was $22 \%$ for males irradiated at the spermatozoa stage, compared with the $8.4 \%$ spontaneous background in non-irradiated parents. Hence, irradiation of post-meiotic germ cells induces minisatellite mutation in F1 mice. In addition, the mutant frequency at the maternally derived allele was also increased in F1 offspring ( $20 \%$ compared with $9.8 \%$ in controls) from irradiated fathers. These results imply that radiation-induced genomic instability causes untargeted mutation of paternal alleles in cis and maternal alleles in trans, and caution about the hazard of paternal DNA damage to the maternally derived genome upon radiation exposure.

\section{References}

1. Mouse minisatellite mutations induced by ionizing radiation.

2. Proceedings of the National Academy of Science, [http://www.pnas.org]

3. Human minisatellite mutation rate after the Chernobyl accident. 